\section{IAVNE FNANCIIE}

\title{
Neka obilježja "kriznog poreza"
}

\section{mr. sc. Ivica Urban}

Na 4. sjednici održanoj 24. srpnja 2009. Vlada RH je predložila Zakon o posebnom porezu na plaće, mirovine i druge primitke ${ }^{1}$ (u nastavku skraćeno: posebni porez na dohodak), koji je u javnosti proteklih dana nazivan i "krizni porez" odnosno "porez solidarnosti". Cilj uvođenja poreza je prikupiti dodatne prihode kako bi se smanjio deficit proračuna središnje države u razdoblju pada BDP-a. U ovom osvrtu analiziramo neka obilježja novog poreza i izračunavamo koliko će se povećati porezni teret za različite dohotke.

Osnovica posebnog poreza na dohodak dobiva se tako da se od plaće, mirovine i "drugog dohotka"2 oduzmu uplaćeni doprinosi, premije osiguranja, te predujam poreza na dohodak i prirez porezu na dohodak. Na tako dobivenu osnovicu primjenjuju se dvije stope, od 2 i $4 \%$. Ako je osnovica manja ili jednaka 3.000 kuna, porez iznosi $0 \mathrm{kuna}^{3}$ Ako je osnovica veća od 3.000 kuna i manja od 6.000 kuna, porez je jednak $2 \%$ osnovice, a ako je osnovica veća od 6.000 kuna, posebni porez na dohodak iznosi $4 \%$ osnovice. ${ }^{4}$

\section{Porez na dohodak i posebni porez na dohodak}

Posebni porez na dohodak sličan je porezu na dohodak ${ }^{5}$, ali ipak postoji nekoliko razlika od kojih ćemo spomenuti samo najvažnije. Prvo, posebni porez na dohodak ne zahvaća dohotke od samostalne djelatnosti, imovine i imovinskih prava, te kapitala i osiguranja. Drugo, posebni porez ne razlikuje obveznike prema broju djece i uzdržavanih članova, te nekim drugim obilježjima, što porez na dohodak čini koristeći različite osobne odbitke i druga umanjenja osnovice i porezne obveze. Treća je razlika u načinu na koji se izračunava porezna obveza: kod poreza na dohodak osnovica (dobivena kao dohodak umanjen za osobne odbitke ${ }^{6}$ ) dijeli se na dijelove i svaki se množi zasebnom stopom, te se umnošci zbrajaju u poreznu obvezu; kod posebnog poreza na dohodak obveznici se prema visini osnovice dijele u tri skupine a zatim se na osnovice druge i treće primjenjuju zasebne stope (2 i 4\%).

\footnotetext{
${ }^{1}$ Prijedlog zakona dostupan je na www.vlada.hr.

2 Pojam "drugog dohotka" definiran je u Zakonu o porezu na dohodak (NN 177/04 i 73/08, čl. 32). Pojednostavljeno, obuhvaća razne vrste honorara i slične primitke.

${ }_{3}^{3}$ Mogli bismo reći da se u tom slučaju na osnovicu zapravo primjenjuje stopa od $0 \%$.

${ }^{4}$ Zanimljivo, iz prijedloga zakona ne možemo zaključiti koja stopa se primjenjuje na osnovicu kada ona iznosi točno 6.000,00 kuna.

${ }^{5}$ Vidjeti Zakon o porezu na dohodak (NN 177/04 i 73/08).

${ }^{6}$ Osnovni osobni odbitak, odbitak za djecu i uzdržavane članove obitelji, te odbici za stambene potrebe, troškove zdravstvenih usluga i dana darovanja.
} 


\section{Manje dohotka je više dohotka?}

Upravo način primjene poreznih stopa kod predloženog posebnog poreza na dohodak uzrokuje jednu anomaliju koju su odmah primijetili algebarski nastrojeni promatrači. U stručnom žargonu, radi se o pojavi granične porezne stope veće od $100 \%$, a koja se inače izbjegava kod oporezivanja dohotka, pa tako i nije prisutna u slučaju našeg poreza na dohodak. O čemu je riječ? Granična porezna stopa (GPS) je omjer povećanja poreza i povećanja dohotka. Razmotrimo to na primjeru. Ako se dohodak obveznika poveća s 1.000 na 1.005 kuna (za 5 kuna), a porez s 200 na 201 kunu (za 1 kunu), to znači da je GPS jednaka $20 \%(=1 / 5 \times 100 \%)$. Ako je GPS manja od $100 \%$, povećanje dohotka rezultirat će povećanjem raspoloživog dohotka (dohotka umanjenog za porez). U tom slučaju isplati se imati veći dohodak. Međutim, ako je GPS veća od $100 \%$, to znači da ćete uz veći dohodak dobivati manje novca (!). Drugim riječima, porez će pojesti svu dodatnu zaradu pa i više od toga.

Od dobro dizajniranog poreza očekuje se da GPS ne prelazi 100\% ni za koju razinu porezne osnovice. Ipak, posebni porez na dohodak pri dva iznosa osnovice izaziva GPS veći od $100 \%$, i to kod osnovica od 3.000 i 6.000 kuna. Naime, ako vam je osnovica 2.999 kuna, posebni porez iznosit će 0 kuna i dohodak nakon poreza će također biti jednak 2.999 kuna. ${ }^{7}$ Međutim, ako vam se osnovica poveća za 2 kune, na 3.001 kune, porez se povećava na 60 kuna; toliko se smanjuje dohodak nakon poreza i iznosi 2.941 kune, odnosno 58 kuna manje nego prije povećanja osnovice. Dakle, povećanje osnovice od dvije kune donijelo je smanjenje dohotka nakon oporezivanja od 58 kuna. Slično vrijedi i za sljedeći primjer. Ako osnovica naraste za dvije kune, s 5.999 kuna na 6.001 kunu, porez raste za 120 kuna. Drugim riječima, na određenim dohodovnim intervalima više se isplati imati manji dohodak nego veći.

S ovim je izravno povezan i teorijski problem rerangiranja. Općenito je prihvaćeno da fiskalni sustav treba smanjivati dohodovne razlike među pojedincima. Međutim, većina se također slaže s propozicijom da fiskalni sustav prilikom preraspodjele treba očuvati rangove pojedinaca na dohodovnoj ljestvici: ako je osoba A imala veći dohodak od osobe $B$ prije fiskalnog djelovanja (oporezivanja ili primanja naknade od države), tada bi trebala imati veći dohodak i nakon fiskalnog djelovanja. U protivnom dolazi do rerangiranja, a upravo se to događa u sustavu novog posebnog poreza na dohodak. Rerangiranje će se javiti, na primjer, za osobu A s osnovicom od 5.990 kuna i osobu B s osnovicom od 6.114 kuna. Osoba A nakon poreza imat će raspoloživi dohodak od 5.870 kuna, što je za 0,76 kuna (76 lipa) više od osobe B.

Raspored poreznih stopa može izazvati rerangiranje, ali nije njegov jedini uzročnik. $\mathrm{Na}$ početku smo spomenuli još dvije razlike posebnog poreza na dohodak u odnosu na porez na dohodak, a tiču se osobnih odbitaka i tretmana pojedinih vrsta dohodaka. Ta dva aspekta oporezivanja dohotka također utječu na rerangiranje. Ne ulazeći u detaljniju analizu, spomenimo samo sljedeće. Porez na dohodak različito tretira obveznike obzirom na broj djece i uzdržavanih članova, tako da će od dvije osobe s jednakim dohotkom manje poreza platiti osoba s više djece i uzdržavanih članova. S druge strane, posebni porez na dohodak ne pravi takve razlike. Nadalje, porez na dohodak pokušava jednako tretirati različite izvore dohotka, na način da obveznik treba na dodatnu kunu dohotka platiti jednak iznos poreza bez obzira na način zarade dohotka ${ }^{8}$ (od plaće, mirovine, honorara, obrta, iznajmljivanja, ...), dok posebni porez na dohodak izjednačuje samo plaće, mirovine i "drugi dohodak".

\footnotetext{
${ }^{7}$ Radi lakše ilustracije pretpostavljamo da su uplaćene premije osiguranja jednake nula. No zaključci koji slijede svakako vrijede i u slučaju postojanja premija osiguranja.

${ }^{8}$ Međutim, mora se spomenuti da i sadašnji porez na dohodak često odstupa od ovog načela. Primjer su neke vrste dohotke koje se oporezuju zasebnim stopama nižim od najviše stope od $45 \%$, a ne treba ih se unositi u godišnju poreznu prijavu. Te stope se razlikuju za pojedine vrste dohotka.
} 


\section{Progresivnost poreza na dohodak}

U javnim raspravama naročito je zastupljena tema tzv. vertikalne pravednosti fiskalnog sustava. Dobivaju li "siromašni" od "bogatih" ili je stanje obrnuto, pitanje je koje se postavlja gotovo svakodnevno, a posebice u danima donošenja rebalansa državnog proračuna. Doprinos toj raspravi ovdje će biti izračun prosječne porezne stope za sljedeću skupinu izravnih poreza: porez na dohodak, prirez porezu na dohodak i posebni porez na dohodak. Želja nam je utvrditi: (a) Koliko je prosječno opterećenje različitih dohodaka ovim porezima? (b) Raste li prosječno opterećenje s dohotkom, odnosno, je li porez progresivan? i (c) Usporediti stanje prije i nakon uvođenja posebnog poreza na dohodak.

Za ilustraciju uzimamo obveznika koji koristi osobni odbitak za jedno dijete i prebiva u mjestu koje ima stopu prireza od $12 \%$. Osnovni osobni odbitak iznosi 1.800 kuna mjesečno, a dodatni osobni odbitak za dijete je 900 kuna. Obveznik ne ostvaruje ostale olakšice. Na vodoravnoj osi grafikona (Slika 1) prikazani su mjesečni dohoci prije poreza na dohodak i nakon plaćanja doprinosa. Prosječna porezna stopa je omjer ukupnog poreza i dohotka. Razmatramo dvije prosječne porezne stope: (1) porezno opterećenje čine porez na dohodak i prirez (plava/tanka crta), i (2) poreznom teretu pridodaje se posebni porez na dohodak (crvena/deblja crta). Dakle, grafikon pridružuje svakom dohotku odgovarajuću prosječnu poreznu stopu za situaciju prije i nakon uvođenja posebnog poreza na dohodak.

Slika 1. Prosječna porezna stopa prije i nakon uvođenja posebnog poreza na dohodak

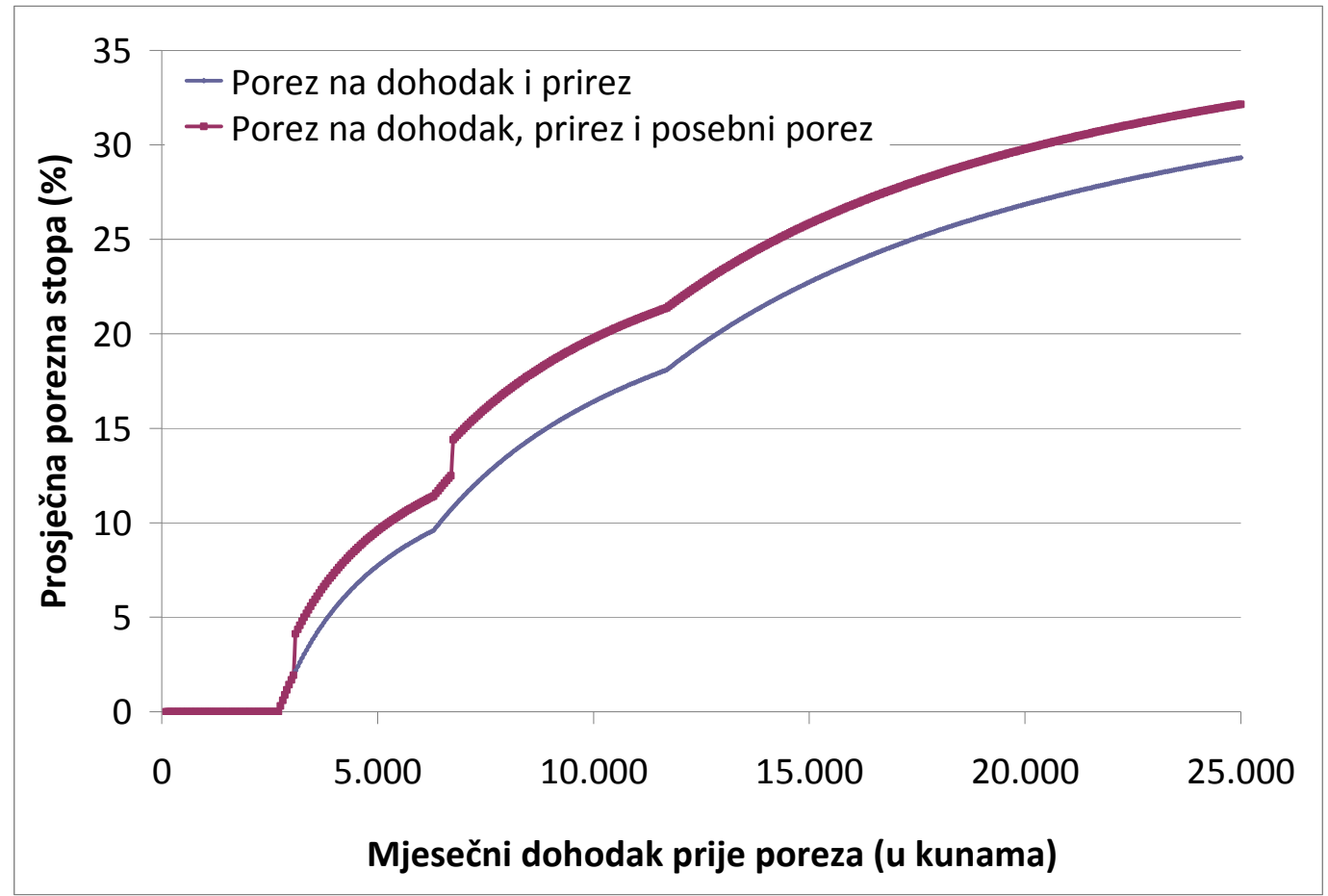

Napomena: Izračun je napravljen za obveznika s jednim djetetom, stopa prireza je $12 \%$.

Prvo treba primijetiti da prosječna porezna stopa u oba slučaja raste s dohotkom: porezi na dohodak relativno više opterećuju obveznike s višim dohocima - ukupni porez je progresivan i prije i nakon uvođenja posebnog poreza na dohodak. ${ }^{9}$ Crvena (deblja) crta koja prikazuje prosječnu poreznu stopu ukupnog poreza, odnosno zbroja poreza na dohodak, prireza $i$ posebnog porez na dohodak, za sve dohotke leži iznad plave (tanke) crte, koja predstavlja prosječnu poreznu stopu zbroja poreza na dohodak i prireza (dakle, bez posebnog poreza na dohodak). To znači da je uvođenjem novog poreza prosječni teret porastao za sve obveznike.

Najveće povećanje tereta snose obveznici s dohotkom većim od 6.700 kuna - porezi im oduzimaju dodatnih 3,5\% dohotka. Nešto manje povećanje tereta, oko $2 \%$ dohotka,

\footnotetext{
${ }^{9} \mathrm{O}$ progresivnosti poreza na dohodak vidjeti Newslettere Instituta za javne financije, dostupne na www.ijf.hr.
} 
doživjet će obveznici s dohotkom između 3.700 i 6.700 kuna. Napomenimo da te granice ovise o visini osobnog odbitka i ovdje su izračunate samo za obveznika koji je uzet za primjer.

Anomalija o kojoj smo detaljno raspravljali u prethodnim odlomcima može se uočiti i na temelju usporedbe dviju prosječnih poreznih stopa na Slici 1. Za crvenu (deblju) crtu, pri dohocima od 3.100 i 6.700 kuna, prosječna stopa "uspravno skače" na razinu veću za oko $2 \%$ (povećanje dohotka od samo 1 kunu donosi pad raspoloživog dohotka za $2 \%$ ). Međutim, to nije slučaj kod plave (tanke) crte jer, kako smo već rekli, porez na dohodak svojim dizajnom izbjegava pojavu granične porezne stope veće od 100\%.

\section{Zaključak}

Predloženi posebni porez na plaće, mirovine i druge primitke poprilično se razlikuje od poreza na dohodak i ne posjeduje neke njegove kvalitete. Ovdje smo razmotrili obilježje novog poreza da izaziva graničnu poreznu stopu veću od $100 \%$, i to za dvije razine dohotka, čime se rerangiraju obveznici na dohodovnoj ljestvici. Rerangiranje se u literaturi a i intuitivno uobičajeno smatra neprikladnim. Dodatno rerangiranje uzrokuje izostanak osobnih odbitaka za djecu i uzdržavane članove te izostanak iz oporezivanja nekih vrsta dohodaka.

Posebni porez na dohodak povećava porezni teret za sve obveznike iznad određene dohodovne granice. Pojedinci s najnižim dohocima i dalje su zaštićeni jer ne plaćaju poreze na dohodak (porez na dohodak, prirez i posebni porez na dohodak). Rast poreznog opterećenja od $2 \%$ dohotka primjetan je za "srednju klasu", a za one s višim dohocima teret raste za 3,5\% dohotka. 